again closes its scales and enters the water. He now again erects the scales, the ants are set floating, and are then swallowed by the anteater.

From a list of the Holothurians in the collection of the Leyden Museum, drawn up by Prof. Dr. Hubert Ludwig of Giessen, we find that the majority of the specimens in the Museum were incorrectly named, which is somewhat surprising; it seems also strange that of the species not so very long since described by Prof. Selenka the specimens are either sine patria or have the rather indefinite habitat of "Indian Ocean." The collection contains fiftytwo species, two being new ; most of them were obtained from the Oriental and Moluccan regions.

In vol. v. Dr. Jentink continues his very useful researches on the squirrels in the Museum. This time he treats of the American, European, and Asiatic squirrels; he acknowledges that the profound and extensive studies upon the American squirrels by Allen and Alston have made this group one of the best known among the Mammals; he enumerates ten species from America, forty from Europe and Asia. All the former are represented generally by numerous examples in the Museum, and of the latter only six species are among the desiderata.

The same volume contains "Notes of new species of the genus Megascolex, Templeton," by Dr. R. Horst. Very satisfactory evidence is given to show that Schmarda's genus Perichæta is but a synonym of Templeton's. Nine new species are described, chiefly from Sumatra, Java, and Japan; one, $M$. musicus, is described as living in the high mountain forests at Java, and is said to make a sharp interrupted noise during the night. The natives call it "tjatjing sondarie."

If in calling attention to these important contributions to our knowledge of the treasures of the Leyden Museum we have passed over the very numerous contributions to entomology, it is simply because our space forbids us referring to the immense number of new genera and species herein described; indeed these notes form a perfect magazine of entomology, and we feel sure are long ere this quite well known to all our entomological readers.

\section{PRZEVALSKY'S WILD HORSE}

Gr

REAT interest is attached to the question of the origin of our domestic animals, and especially to that of the horse-which is generally supposed not now to exist in an aboriginally wild state. Every fact bearing upon this subject is of importance, and the discovery by the great Russian traveller, Przevalsky, of a new wild horse, more nearly allied to the domestic horse than any previously known species, is certainly. well worthy of attention.

The horses, which constitute the genera Equus of Linnæus, and are the sole recent representatives of the family Equidce, fall naturally into two sub-genera, as was first shown by Gray in 1825 (Zool. Journ. i. p. 24I) Equus and Asinus.

The typical horses (Equus) are distinguishable from the asses (Asinus) by the presence of warts upon the hindlegs as well as upon the fore-legs, by their broad rounded hoofs, and by their tails beginning to throw off long hairs from the base, instead of having these hairs confined, as a sort of pencil, to the extremity of the tail. Up to a recent period all the wild species of Equus known to science were referable to the second of these sections, that is, to the sub-genus Asinus, known from Equus by the absence of warts or callosities on the hind-legs, by the contracted hoofs, and by the long hairs of the tail being restricted to the extremity of that organ. Of this group the best known species, commonly called wild asses and zebras, are (I) the wild ass of Upper Nubia (Equus taniopus), probably the origin of the domestic ass; (2) the wild ass of Persia and Kutch (E. onager); $(3)$ the hemippe or wild ass of the Syrian Desert (E. hemippus); (4) the kiang or wild ass of Tibet (E. hemionus); (5) the quagga (E. quagga) of South Africa; (6) the Burchell's zebra (E. burchelli) of Southern and Eastern Africa; ( 7$)$ the zebra (E. zebra) of Southern Africa. As already stated, these seven animals all possess the characters of the second sub-genus Asinus as above given, and no recent species of horse referable to the first sub-genus (Equus) was hitherto known to exist on the earth's surface, except the descendants of such as had been formerly in captivity.

Under the circumstances great interest was manifested when it was known that Przevalsky, on his return from his third great journey into Central Asia, had brought back with him to St. Petersburg an example of a new species of wild horse, which belonged, in some of its characters at least, to true Equus.

This new animal was described in $188 \mathrm{r}$ in a Russian journal by Mr. J. S. Poliatow, and dedicated to its discoverer as Equus przevalskii.

The recently issued German translation of Przevalsky's third journey ${ }^{1}$ enables us to give further particulars of this interesting discovery.

Przevalsky's wild horse has warts on its hind-legs as well as on its fore-legs, and has broad hoofs like the true horse. But the long hairs of the tail, instead of commencing at the base, do not begin until about half-way

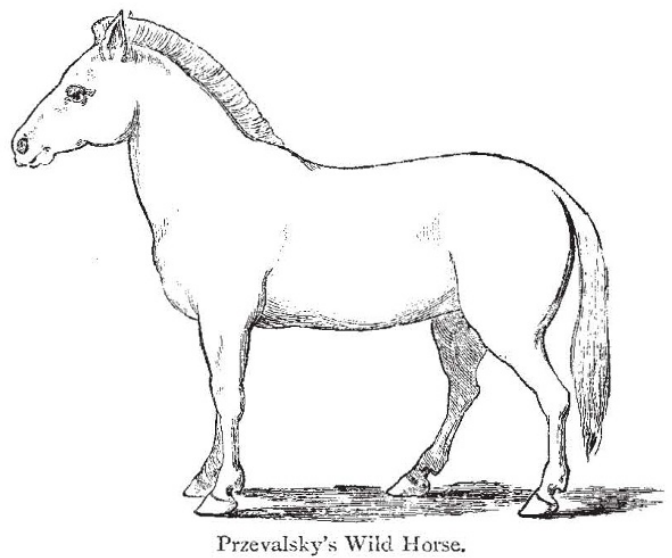

down the tail. In this respect Equus praevalskii is intermediate between the true horse and the asses. It also differs from typical Equus in having a short, erect mane, and in having no fore-lock, that is, no bunch of hairs in front of the mane falling down over the forehead. Nor has Przevalsky's horse any dorsal stripe, which, although by no means universal, is often found in the typical horses, and is almost always present in the asses. Its whole general colour is of a whitish gray, paler and whiter beneath, and reddish on the head. The legs are reddish to the knees, and thence blackish down to the hoofs. It is of small stature, but the legs are very thick and strong, and the head is large and heavy. The ears are smaller than those of the asses.

Przevalsky's wild horse inhabits the great Dsungarian Desert between the Altai and Tianschan Mountains, where it is called by the Tartars "Kertag," and by the Mongols "Statur." It is met with in troops of from five to fifteen individuals, led by an old stallion. Apparently the rest of these troops consist of mares, which all belong to the single stallion. They are lively animals, very shy, and with highly-developed organs of sight, hearing, and smelling.

They keep to the wildest parts of the desert, and are

I "Reisen in Tibet und am oberen Laut des Gelben Flusses in den Jahren Deutsche übertragen von Stein-Nordhcim. (Jena, 1884.) 
very hard to approach. They seem to prefer especially the saline districts, and to be able to do long without water.

The pursuit of this wild horse can only be carried on in winter, because the hunter must live in the waterless districts, and must depend upon a supply of water from melted snow. As may well be believed, such an expedition during the severest cold of winter into the most remote part of the desert, must take at least a month. During the whole time of his stay in the Dsungarian Desert, Przevalsky met with only two herds of this wild horse.

In vain he and his companions fired at these animals. With outstretched head and uplifted tail the stallion disappeared like lightning, with the rest of the herd after him. Prezevalsky and his companions could not keep near them, and soon lost their tracks. On the second occasion they came upon them from one side, yet one of the herd discovered their presence, and they were all gone in an instant.

The single specimen of Przevalsky's horse subsequently procured is now in the Museum of the Academy of Sciences of St. Petersburg, and is the only example of this species in Europe.

THE DIFFERENCE BETWERN THE SEA AND CONTINENTAL CLIMATE WITH REGARD TO VEGETATION

TH $\mathrm{E}$ difference in vegetation between the sea and continental climate is no doubt best observed in the growth of plants generally cultivated in the temperate zone for different purposes, as every climate has its own region or flora. Whether the climate of a country is favourable to those plants or not is shown, in the first place, by their extension to the north; therefore we shall first endeavour to trace the northern limits of the most important plants, either cultivated in one country and growing wild in another, or cultivated everywhere.

To the first class trees mostly belong; to the second, annual or perennial plants. We begin with trees :-

Pinus sylvestris, L. (Scotch pine). Scotland, $59^{\circ}$; Norway, $70^{\prime \prime} 20^{\prime}$; Kola, $69^{\circ}$; Petchora region, $67^{\circ} 15^{\prime}$; $\mathrm{Ob}$ River, $66^{\circ}$; Turukansk, $65^{\circ}$. The Verkhoyansk Mountains, east of the Lena River $\left(64^{\circ}\right)$, are the eastern limits of this tree. ${ }^{1}$

Betula odorata, Bechst. (alba, L., var.) (birch). Greenland, $61^{\circ}$ (shrub); Iceland, $65^{\circ}$ (shrub to ten feet high); Britain, $59^{\circ}$; Norway, $70^{\circ} 50^{\prime}$; Kola Peninsula, $69^{\circ} 30^{\prime}$; Kanin Peninsula, $67^{\circ}$; to the $\mathrm{Ob}$ River $\left(66^{\circ}\right)$, and from the River Kolyma $\left(68^{\circ}\right)$ to the Penshina Gulf $\left(63^{\circ}\right)$ and Kamchatka ; on this peninsula it is a large tree.

Quercus pedunculata, Ehrh. (Q. robur, L., var.) (common oak). England, 58 ; Norway (wild), to $62^{\circ} 55^{\circ}$, and cultivated to $65^{\circ} 54^{\prime}$; Finland (coast), $61^{\circ} 30^{\prime}$ (Bjorneborg) ; St. Petersburg, Yaroslav, Perm, $5^{80.2}$

Larix europcea, Dec. (including L. sibirien. Ledeb., and L. dahurica, Turcz) (common larch). Norway (europaca, Dec.), $66^{\circ} 5^{\prime}$, (dahurica, Turcz), $59^{\circ} 55^{\prime}$, both cultivated; Onega River, White Sea, south-western shore of Onega Lake, Mesen (Kanin Peninsula), $67^{\circ}$; Petchora River, $67^{\circ} 30^{\prime}$; Ural Mountains, $67^{\circ} 15^{\prime}$; Kara River, $68^{\circ}$ (northern limit in Europe); Yenisei River, 70 ; Boganida River, $71^{\circ} 15^{\prime}$; Chatanga River, $72^{\circ} 30^{\prime}$ (most northern limit of trees on the globe); Anabar, $7 \mathrm{I}^{\circ}$; Olenek and Lena, $72^{\circ}$; Yana, $71^{\circ}$; Indigirka, $70^{\circ} 45^{\prime}$; Kolyma, $69^{\circ}$; Anadyr, $65^{\circ}$; between Okotsk and Gishiga, $6 \mathrm{I}^{\circ}$; Sakalin Peninsula, $49^{\circ}$; to Jeddo and the island of Kunaschir, $43^{\circ} 45^{\prime}$. On the shores of Kamchatka the larch is nowhere to be found; in the valleys of this peninsula, however, protected from sea winds, it is a very large tree. ${ }^{3}$

$$
\text { "Middendorff, "Sibirische Reise," Bd. iv. Th. } x, \text { p. } 556 .
$$

Pyrus Malus, L. (apple-tree). Shetland Isles (cultivated); Britain, $57^{\circ}$; Norway, cultivated, $65^{\circ} 28^{\prime}$, wild, $63^{\circ} 4 \mathrm{o}^{\prime}$; Gulf of Bothnia, $63^{\circ} 45^{\prime}$ (cultivated); Finland, $63^{\circ}$ (cultivated), $60^{\circ}$ (wild); northern shore of Onega Lake (wild); Narva, $59^{\circ} 30^{\prime}$ (wild); Tver, $56^{\circ} 45^{\prime}$ (wild); Nijni Novgorod, $56^{\circ}$ (wild); Kasan, $56^{\circ}$ (wild); south-west of Orenburg, $50^{\circ}$; Kopal, Asia, $45^{\circ}$.

Fagus sylvatica, L. (common beech). Britain, 58 ; Norway, $59^{\circ}$, cultivated, $67^{\circ} 56^{\prime}$; Sweden, $57^{\circ}$; Königsberg, Poland, South-West Russia, Crimea, Caucasus, Persia.

Castanea vesca, Grtn. (chestnut). South Britain, Germany (to the island of Ruigen), Austria, Caucasus.

Populus alba, L. (abele tree). Britain (wild and cultivated), $56^{\circ}$; Norway (cultivated), $67^{\circ} 56^{\prime}$; Germany (wild and cultivated), Austria, Russia: Volhynia, Kieff, Charkoff, Tambov, Kasan, Ufa, Altai Mountains.

Populus tremula, L. (aspen). Britain, 59 ; Norway, $70^{\circ} 37^{\prime}$; Russia: Kola Peninsula, $69^{\circ} 30^{\prime}$; eastern shores of the White Sea, $66^{\circ}$; Yenisei, $66^{\circ}$; Kolyma River, $67^{\circ} 30^{\prime} ;{ }^{1}$ Amur River.

Alnus incanc, W. (hoary-leaved elder). Canada, Norway, $70^{\circ} 30^{\prime}$; Kola, $69^{\circ} 30^{\prime}$; Yenisei, $67^{\circ}$; Amur region, Petropaulovsk on Kamchatka.

Ulmus campestris, L. (common elm-tree). Britain, $57^{\circ}$; Norway (cultivated), $63^{\circ} 26^{\prime}$; Russia: Ilmen Lake, south of Moscow, Riazan, south of Kazan and Ufa to the Ural Mountains.

Tilia europae, L. (including parvifolia, grandifolia, and intermedia) (lime-tree). Britain, $57^{\circ}$ (parvifolia); Norway (wild), $62^{\circ} 9^{\prime}$, (cultivated) $67^{\circ} 5^{6^{\prime}}$; St. Petersburg, Kargopol, Ust Süssolsk, about $62^{\circ}$; Solikamsk, Ural Mountains, about $58^{\circ} 50^{\prime}$; Verkhoturgi.

Vitis vinifera, L. (common grape). Bretagne, $47^{\circ} 30^{\prime}$; Liége, $50^{\circ} 45^{\prime}$; Thuringia to Silesia, $5 \mathrm{I}^{\circ} 55^{\prime}$; South Galicia, South Russia, between about $48^{\circ}$ and $49^{\circ}$; Astrakan, Bokhara in Turkestan, $40^{\circ}$ (here the vine is cultivated in the open fields ${ }^{2}$ ) ; Khiva, $42^{\circ}$; China, $40^{\circ}$; California. This plant cannot stand the extreme continental climate on account of the frost in winter, but wants a very warm or a very long summer (as in California), therefore it cannot be cultivated generally in Britain. California is warmer in summer than some latitudes in Europe.

Triticum vulgare, Vill, var. astivum (summer wheat). Britain ; Norway, in the fields, $64^{\circ} 40^{\prime}$, in gardens, $69^{\circ} 28^{\prime}$; Finland, $65^{\circ} ;{ }^{3}$ Dwina River, $63^{\circ}$; Yakutsk, western

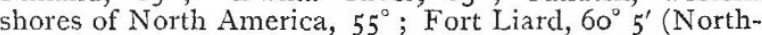
West Territory of Canada); ${ }^{4}$ Peace River, $56^{\circ} 6^{\prime}$; Ontario, East Canada.

Hordeum vulgare, L. (including hexastichum) (barley). Färoe Isles, $62^{\circ}$ I $5^{\prime}$ (grain seldom ripens); Norway, $70^{\circ}$; western shores of the White Sea, $67^{\circ}$; Ob River, $61^{\circ}$; Yakutsk, $62^{\circ}$; Udskoi Ostrog, near the Okotsk Sea, $54^{\circ} 30^{\prime}$; Kamchatka (inland), $53^{\circ}$ to $54^{\circ}$; North-West American shore, south of Sitka, $57^{\circ}$; Fort Norman, Mackenzie River, $65^{\circ} ;{ }^{5}$ east of Winnipeg, $50^{\circ}$; St. Lawrence Bay, $50^{\circ}$.

Avena sativa, L. (oat). Scotland; Norway, $69^{\circ} 28^{\prime}$; Finland, $69^{\circ}$; Asia, the same latitude as Hordeum vulgare; Yenisei, $6 \mathrm{r}^{\circ}$; Yakutsk, Kamchatka (inland); North America, the same latitude as Hordeum vulgare.

Secale cereale, L. (common rye). Britain; Norway, $69^{\circ} 30^{\prime}$; Finland, $67^{\circ}$; Mesen River, $65^{\circ} 45^{\prime}$; Petchora region, $65^{\circ} 45^{\prime}$; Ural Mountains, $57^{\circ}$; Ob River, $60^{\circ}$; Yenisei, $59^{\circ} 30^{\prime}$; Yakutsk, Kamchatka (inland); North America, a little south of the latitude of the barley, eastern shores, $50^{\circ}$.

Solanum tuberosum, L. (potato). Britain ; Norway, $71^{\circ} 7^{\prime}$;

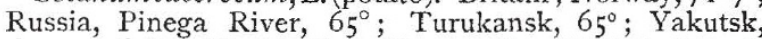
shores of the Okotsk Sea, Kamchatka, Kadjah Island,

1 Middendorff, p. 573 .

Grisebach, "Die Vegetation der Erde," vol. i. p. 407

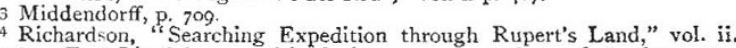
p. 267 . Fort Liard has an altitude between 400 and 500 feet above sea.
level. 